Article

\title{
Spirometric Lung Function Tests in School Children with Asthma
}

\author{
Jesmin Ara Begum ${ }^{1}$, Mohammad Imnul Islam² , Abdul Matin ${ }^{3}$
}

\begin{abstract}
Background: Asthma is one of the important chronic disorder in childhood, the incidence of paediatric asthma is increasing in many countries. Atopy is highly associated with childhood asthma. Spirometric measurements of lung function are playing a key role in the diagnosis and management of asthma in children. Objective: To observe the lung function status in asthmatic children aged $6-15$ years of both sexes. Method: The present observational study was carried out in the Department of Physiology, Ibrahim Medical College, Dhaka between January 2010 and June 2010. For this, 30 asthmatic children were selected from Out Patient Department of Paediatric, Dhaka Medical College as a case and 30 apparently healthy children were taken as control. Subjects with history of pneumonia, congenital heart disease were excluded from the study. Spirometry was conducted on all patients by using

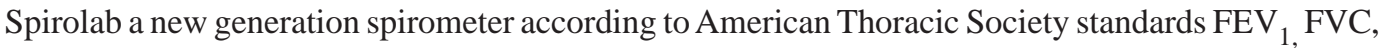
$\mathrm{FEV}_{1} / \mathrm{FVC} \%$ were measured. Measurement of PEFR was also done at the same time by using a new Mini-Wright Peak Flow Meter. Serum Ig-E level was measured by ELISA method and circulating eosinophil count was also measured by observing in peripheral blood flim. Data were analyzed by using SPSS. Statistical analysis was performed by unpaired student t test. Results: The mean percentages of predicted values $\mathrm{FEV}_{1}$, FVC, $\mathrm{FEV}_{1} / \mathrm{FVC}$, PEFR were significantly lower in asthmatic children compared to those of apparently healthy children $(\mathrm{P}<0.001)$. Statistically significant differences of mean circulating eosinophil count and Ig $\mathrm{E}$ level( $\mathrm{P}<0.001)$ were observed between the groups. Again significant number of parents of the subject had history of allergic rhinitis. Conclusion: The outcome of this study shows lung function status were lower in asthmatic children.
\end{abstract}

J Bangladesh Soc Physiol. 2010 December; 5(2): 75-79 For author affiliations, see end of text.

http://www.banglajol.info/index.php/JBSP

\section{Introduction}

A

sthma is one of the important chronic disorder in children. Incidence of paediatric asthma is increasing day by day in many countries ${ }^{1 .}$ According to First National Asthma Prevalence Study (NAPS, 1999) in Bangladesh about 7 million people (5.2\% of the population) are suffering from current asthma (at least three episodes of asthma attack in last 12 months). Unfortunately, majority of these patients were in $1-15$ years of age group. $7.4 \%$ of the total paediatric population of our country are suffering from asthma ${ }^{2}$. Atopy is highly associated with childhood asthma ${ }^{3}$. Exposure to environmental factors, particularly inhalant allergens is commonly reported as a precipitant of acute exacerbations of asthma ${ }^{4}$. Asthma due to allergy is often associated with a personal and family history of allergic diseases such as rhinitis, urticaria and eczema with positive wheal and flare skin reactions to injection of intradermal indoor and outdoor airborne allergens ${ }^{5}$. 
Spirometric lung function tests are playing a key role in the diagnosis and management of asthma in children ${ }^{6}$. Normal lung function is one of the goal of asthma management in international guidelines ${ }^{7,8}$. Furthermore, the long term cohort studies have established that lung function test results in children with asthma are correlated with asthma severity and with lung function impairment in adulthood ${ }^{9}$. There is evidence that spirometric measurement of lung function including $\mathrm{FEV}_{1}, \mathrm{FVC}, \mathrm{FEV}_{1} / \mathrm{FVC}$ and PEFR are decreased in asthmatic children than those of the apparently healthy children ${ }^{10}$.

It has also been reported that there will be a dramatic increase in serum Ig E levels in asthmatic children than those of the apparently healthy children ${ }^{11}$. Lower values of spirometric lung fuction parameters had also been reported by some other investigators of different countries ${ }^{6,12}$. The aim of this study was to compare the spirometric lung fuction parameters like $\mathrm{FEV}_{1}$, FVC, $\mathrm{FEV}_{1} / \mathrm{FVC}$ and PEFR in children with asthma and also in apparently healthy children. Atopic markers like Ig E and circulating esinophil count were also measured in this population in order to find out the presence of atopic conditions like asthma, allergic rhinitis, eczema.

\section{Method}

This cross sectional study was carried out in the Department of Physiology, Ibrahim Medical College, Dhaka between January 2010 and June 2010. Protocol of this study was approved by ethical committee of this institution. Thirty apparently healthy children were taken as control, and 30 children suffering from asthma were selected as a case and their age ranged from 6- 15 years \& of both sexes. All the children of both the groups were the residents of different areas in Dhaka city. Subjects with history of pneumonia, congenital heart disease, acute exacerbation of asthma, patients with oral steroids, hospitalization during last four weeks were excluded from the study.

After selection, all the subjects were briefed about the objectives and benefits of the study to ensure their voluntary participation. Informed written consent was taken from each subject prior to the study. After selection, all the subjects were asked to attend the Department of Physiology, Ibrahim Medical College, Dhaka for lung function test. All relevant informations were recorded in a prestructured questionnaire.

For assessing lung function FVC, FEV1,FEV1 / $\mathrm{FVC} \%$ and PEFR were measured at normal room temperature by using Spirolab a new generation spirometer according to American Thoracic Society standard. Subjects with asthma were instructed to withheld their bronchodilator medications for at least eight hours before doing lung function tests. Peak flow measurement was also done at the same time by using a new MiniWright Peak Flow Meter. Spirometric data were expressed as a percentage of predicted values (\% pred), using prediction equations based on age, sex and height ${ }^{13}$

Serum Ig-E level was measured by Enzyme Linked Immunosorbent Assay method in all subjects and circulating eosinophil count was also measured in peripheral blood film by Improved Double Neubauer counting chamber.

Statistical analysis was done using SPSS windows package version 12 . The comparisons between the two groups were done by unpaired student $t$ test.

\section{Results}

General characteristics of the study population were presented in Table I. No statistically significant differences were observed between the groups in relation to age and BMI. So they were matched for age $\&$ BMI.

Table I: General characteristics of the study children $(n=60)$

\begin{tabular}{lcc}
\hline Parameters & $\begin{array}{c}\text { Control } \\
(\text { Mean } \pm \text { SD }) \\
(\mathrm{n}=30)\end{array}$ & $\begin{array}{c}\text { Case } \\
(\text { Mean } \pm \text { SD }) \\
(\mathrm{n}=30)\end{array}$ \\
\hline Age (years) & $8.92 \pm 1.93$ & $7.30 \pm 1.77$ \\
BMI $\left(\mathrm{kg} / \mathrm{m}^{2}\right)$ & $18.42 \pm 2.84$ & $17.20 \pm 3.10$ \\
\hline
\end{tabular}


Article

Results of lung function parameters are shown in Table II. Measured values of Mean $\mathrm{FEV}_{1}$, $\mathrm{FVC}, \mathrm{FEV}_{1} / \mathrm{FVC} \%$, PEFR are expressed as percentage of their correspondings predicted value. Percentage of predicted values $>80 \%$ for FVC and FEV1 and $75 \%$ for FEV1 / FVC \% were considered as normal.

All these parameter were significantly lower ( $\mathrm{P}$ $<0.001)$ in asthmatic children compared to those of healthy children .
Spirometric Tests in School Children

Mean IgE level and circulating eosonophil count were significantly $(\mathrm{P}<0.001)$ higher in asthmatic children than those of healthy children (Table III )

In the family of the study children, allergic rhinitis were found $50 \%$ and $46.7 \%$ in case and control respectively. Asthma and Eczema were found $23.3 \%$ and $3.3 \%$ respectively in only case group. Allergic rhinitis plus asthma and Allergic rhinitis plus eczema were found 10\% of cases (Table IV).

Table II : Lung function parameters in study children $(\mathrm{n}=60)$

\begin{tabular}{|c|c|c|c|c|}
\hline $\begin{array}{l}\text { Parameters / } \\
\text { Groups }\end{array}$ & $\begin{array}{c}\text { Measured } \\
\mathrm{n}\end{array}$ & $\begin{array}{c}\text { Predicted } \\
\text { (Mean } \pm \text { SD) }\end{array}$ & $\begin{array}{l}\text { Predicted \% } \\
(\text { Mean } \pm \text { SD) }\end{array}$ & $($ Mean $)$ \\
\hline \multicolumn{5}{|l|}{$\mathrm{FEV}_{1}(\mathrm{~L} / \mathrm{sec})$} \\
\hline Control & 30 & $1.45 \pm 0.34$ & $1.71 \pm 0.43$ & $84.95 \pm 4.89$ \\
\hline Case & 30 & $0.91 \pm 0.42$ & $1.31 \pm 0.45$ & $67.95 \pm 12.59^{* * *}$ \\
\hline \multicolumn{5}{|l|}{ FVC (L/sec) } \\
\hline Control & 30 & $1.65 \pm 0.42$ & $1.93 \pm 0.51$ & $85.85 \pm 5.05$ \\
\hline Case & 30 & $1.03 \pm 0.45$ & $1.48 \pm 0.53$ & $68.68 \pm 11.74^{* * *}$ \\
\hline \multicolumn{5}{|l|}{$\mathrm{FEV}_{1} / \mathrm{FVC}(\%)$} \\
\hline Control & 30 & $89.13 \pm 3.71$ & $89.01 \pm 2.46$ & $100.18 \pm 4.12$ \\
\hline Case & 30 & $84.28 \pm 4.92$ & $88.81 \pm 3.86$ & $95.11 \pm 7.36^{* * *}$ \\
\hline \multicolumn{5}{|l|}{ PEFR(L/min) } \\
\hline Control & 30 & $202.83 \pm 35.64$ & $239.90 \pm 42.99$ & $84.69 \pm 3.74$ \\
\hline Case & 30 & $150.17 \pm 54.56$ & $209.87 \pm 57.07$ & $70.79 \pm 13.22^{* * *}$ \\
\hline
\end{tabular}

All the parameters are expressed as percentage of predictated values. Statistical analysis was done by unpaired students $\mathrm{t}$ test

Control: non asthmatic children .

Case: asthmatic children

*** = Significant at $\mathrm{P}<0.001$

$\mathrm{n}=$ number of subjects

Table III: IgE level and Circulating eosinophil count of the study children ( $\mathrm{n}=60)$

\begin{tabular}{lccc}
\hline & $\begin{array}{c}\text { Control } \\
\text { Parameters }\end{array}$ & $\begin{array}{c}\text { Case } \\
(\mathrm{Mean} \pm \mathrm{SD}) \\
(\mathrm{n}=30)\end{array}$ & $\begin{array}{c}\text { Mean } \pm \mathrm{SD}) \\
(\mathrm{n}=30)\end{array}$ \\
\hline CE count $(\mathrm{cmm})$ & $188.50 \pm 142.62$ & $417.30 \pm 261.76$ & value \\
IgE $(\mathrm{IU} / \mathrm{ml})$ & $111.57 \pm 94.39$ & $436.73 \pm 465.71$ & $0.0001^{* * *}$ \\
\hline
\end{tabular}

All the parameters are expressed as percentage of predictated values . Statistical analysis was done by unpaired students t test.

Control: non asthmatic children.

Case: asthmatic children

*** = Significant at $\mathrm{P}<0.001$

$\mathrm{n}=$ number of subjects 
Spirometric Tests in School Children

Article

Table IV: Distribution of subjects of their family history $(\mathrm{n}=60)$

\begin{tabular}{|c|c|c|c|c|c|}
\hline \multirow[t]{2}{*}{ Disorders } & \multicolumn{2}{|c|}{$\begin{array}{l}\text { Control } \\
(\mathrm{n}=30)\end{array}$} & \multicolumn{2}{|c|}{$\begin{array}{l}\text { Case } \\
(\mathrm{n}=30)\end{array}$} & \multirow[t]{2}{*}{$\begin{array}{c}\mathrm{P} \\
\text { value }\end{array}$} \\
\hline & No. & (\%) & No. & (\%) & \\
\hline None & 16 & (53.3) & 1 & (3.3) & \\
\hline Asthma & 0 & & 7 & (23.3) & \\
\hline Eczema & 0 & & 1 & (3.3) & \\
\hline Allergic rhinitis & 14 & (46.7) & 15 & (50.0) & $0.0001^{* * *}$ \\
\hline \multicolumn{6}{|l|}{ Allergic rhinitis } \\
\hline plus asthma & 0 & & 3 & (10.0) & \\
\hline \multicolumn{6}{|l|}{ Allergic rhinitis } \\
\hline plus eczema & 0 & & 3 & (10.0) & \\
\hline
\end{tabular}

\section{Discussion}

The present study, was undertaken to observed the percentages of predicted values of FVC ,FEV1, FEV1/FVC \% ,PEFR and also IgE level, circulating eosinophil count in asthmatic children .All these parameters were also studied in apparently healthy children.

In the present study, the percentages of predicted mean $\pm \mathrm{SD}$ mean values of $\mathrm{FEV}_{1}, \mathrm{FVC}$, $\mathrm{FEV}_{1} / \mathrm{FVC} \%$, PEFR were significantly lower in asthmatic children comparison to those of apparently healthy children. All these findings are consistent with the findings of some investigators of different countries. A study by Eugene $^{6}$ found similar observations in similar group of children ${ }^{15}$.

Allergy is highly associated with childhood asthma. Serum Ig-E and circulating eosinophil counts were measured in this study. In this study significantly raised mean serum Ig-E and eosinophil counts were found in asthmatic children compared to those of healthy children. Siroux et al found significantly increased serum Ig-E but eosinophil count was not related to asthma children . Increased Ig-E was also found in asthmatic children in some other study ${ }^{16}$. Some studies have demonstrated atopic markers to be strongly associated with childhood asthma ${ }^{17}$, but this is not a consistent finding ${ }^{18}$.

Atopic condition in the parents of the study children were identified in this study. Allergic rhinitis, Asthma, Eczema were found in the parents of asthmatic children. Sandra et al showed similar findings in their study ${ }^{15}$. The children who suffers from bronchial asthma with atopy had their family history of allergic rhinitis which is in favor of presence of allergic bronchial asthma in children of our population .

\section{Conclusion}

From this study it can be concluded that asthma children are suffering from poor pulmonary function. For this, early diagnosis of atopy and asthma may be helpful to minimize the subsequent complications specially to children.

\section{Author affiliations}

1. Jesmin Ara Begum. Associate Professor, Department of Physiology, Ibrahim Medical College. Shahbag, Dhaka-1000. Email: imnul27@yahoo.com

2. Mohammad Imnul Islam²Assistant Professor, Department of Paediatrics, Dhaka Medical College.

3. Abdul Matin Assistant Professor, Department of Paediatrics, Shaheed Shurawardy Medical College.

* For correspondence 


\section{Article}

\section{References}

1. Lenny $\mathrm{W}$.The burden of pediatric asthma. Pediatr pulmonol suppl 1997; 15:13 -16.

2. Hassan MR et al. Self reported Asthma symptomsin children in children and adults of Bangladesh: Findings of The First National Asthma Prevalence Study. In J Epidemiol 2002; 31: 483-88.

3. Siroux , Oryszczyn M-P , Paty E , Kauffmann F , Pison C, Vervolet D, Pin I et al . Relationships of allergic sensitization, total immunoglobulin $\mathrm{E}$ and blood eosinophils to asthma severity in children of the EGEA sudy . Clin Exp Allergy 2003 Jun ; 33 (6) : 746-51 .

4. Leonard B Bacharier, Chistopher Dawson, Gordon R Bloomberg, Bruce Bender, Laura Wilson et al. Hospitalization for asthma: Atopic, Pulmonary Function, and psychological correlates among participants in the childhood asthma management program. Paediatrics 2003;112(2):e85-92.

5. Mcfadden ER. Jr Asthma, In: Issel bacher KJ, Brannwald E, Wilsonanan JD, Martin JB, Fanci AS, Karper DL, editors, Harrison's Principles of Internal Medicine $13^{\text {th }}$ ed.New York:McGraw-Hill, Inc; 2005: pp. 1508-1515.

6. Eugene Y, Woojung K, Byoung CK, Sung Y C, Myung H S, Kyu E K. Relationship among pulmonary function, bronchial hyperresponsiveness, and atopy in children with clinically stable asthma. Lung 2006; 73-79

7. Global Initiative for Asthma (GINA) . Global strategy for asthma management and prevention. Washington, DC: National Institutes of Health, National Heart, Lung and Blood Institutes ; February 2002. Publication No. 02 -3659 .

8. British Thoracic Society.British guideline on the management of asthma .Thorax 2003; 58 ( suppl 1) : i17 -i28 .

9. Rasmussen F, Taylor DR, Flannery EM, Cowan JO ,Greene JM ,Herbison GP ,Scars MR .Risk factors for airway remodeling in asthma manifested by a low postbronchodilator FEV1/ vital capacity ratio
: a longitudinal population study from childhood o adulthood. Am J Respir Crit Care Med 2002 ; 165 : 1480 -88 .

10. Ulrick C S, Backer V. Markers of impaired growth of pulmonary function in children and Adolescents. Am J Respir Crit Care Med 1999; 160: 40-44.

11. T F Leung, G W K Wong, F W S Ko, C W K Lam, T F Fok. Clinical and atopic parameters and airway inflammatory markers in childhood asthma: a factor analysis. Thorax 2005;60: 822-826

12. Nysom K, C S Ulrick, B. Hesse, A Drickson. Published models and local data can bridge the gap between reference values of lung function for children and adults. Eur Respir J 1997;10: 159198.

13. Ulrick C S, Backer V. Atopy in Danish children and adolescents: results from a longitudinal population study. Annals of Allergy, Asthma, Immunology 2000; 85: 293-97.

14. Sandra A R, Tatiana F, Simone S, J Roberto. Atopy, passive smoking, respiratory infections and asthma among children from kindergarten and elementary school. Sao Paulo Med J 2002; 120(4):109-12

15. Mariam Naqvi, Shweta Choudhry, Hui- Ju Tasi, Shannon Thyne, Daniel Navarro et al. Association between Ig -E levels and asthma severity among African American, Mexican. and Puerto Rican patients with asthma. J Allergy Clin Immunol 2007; 120:137-43.

16. Burrows B, Martinez FD, Halonen M. Association of asthma with serum Ig E levels and skin test reactivity on allergens. N Eng J Med 1989; 320: 271-7.

17. Pearce N, Pekkanen J, Baesly R. How much asthma is really attributable to atopy? Thorax 1999; 54:268-72.

18. Penny M E, Murad S, Madrid S S, Herrera T S, Pinerio A et al . Respiratory symptoms, asthma, exercise test spirometry, and atopy in school children from a Lima shanty town. Thorax 2001;56: 607-12. 